\title{
Mansonella ozzardi in Brazil: prevalence of infection in riverine communities in the Purus region, in the state of Amazonas
}

\author{
Jansen Fernandes Medeiros ${ }^{1 /+}$, Victor Py-Daniel ${ }^{2}$, Ulysses Carvalho Barbosa ${ }^{2}$, Thiago Junqueira Izzo $^{3}$ \\ ${ }^{1}$ Coordenação de Pesquisas em Ciências da Saúde ${ }^{2}$ Núcleo de Pesquisas em Ciências Humanas e Sociais \\ ${ }^{3}$ Coordenação de Pesquisas em Ecologia, Instituto Nacional de Pesquisas da Amazônia, CP 478, 69011-970 Manaus, AM, Brasil
}

\begin{abstract}
This study was undertaken to investigate the prevalence of Mansonella ozzardi infection and to estimate the parasitic infection rate (PIR) in simuliid black flies in the municipality of Pauini, Amazonas, Brazil. We used thick blood films to examine 921 individuals in 35 riverine communities along the Pauini and Purus Rivers. Simuliids were caught in several communities. Flies were identified, stained with haematoxylin and dissected. Overall, 44 (24.86\%) of 177 riverines were infected in communities on the Pauini River and $183(24.19 \%)$ of 744 on the Purus. The prevalence was higher in men (31.81\% and 29.82\%) than in women (17.98\% and 19.18\%) and occurred in most age groups. The prevalence increased sharply in the 28-37 (50\% and 42.68\%) age group and increased in the older age classes. The highest prevalence was in farmers (44\% and 52.17\%, respectively) in the Pauini and Purus Rivers. Only Cerqueirellum amazonicum (Simuliidae) transmits M. ozzardi in this municipality, and we found a PIR of 0-8.43\% and infectivity rate of $0-3.61 \%$. These results confirm that rates of $\mathrm{M}$. ozzardi infection are high in Pauini and suggest that its prevalence may be far greater than has been previously reported due to the absence of a program for treating the population.
\end{abstract}

Key words: Mansonella ozzardi - mansonelliasis - simuliid vector - Amazonas - Brazil - Cerqueirellum amazonicum

The filaria Mansonella ozzardi, one of the aetiological agents of mansonelliasis, is found on the American continent, as well as countries in the Caribbean. In South America, it has been reported in Panama, Colombia, Venezuela, Guyana, Suriname, Brazil, Argentina and Peru (Kozek et al. 1982). M. ozzardi is transmitted by Diptera insects of the families Ceratopogonidae in the Caribbean islands and Ceratopogonidae and Simuliidae in Central and South America (Shelley \& Coscarón 2001).

The pathogenicity of this filaria is not well defined. Several infected individuals show no symptoms; however, clinical manifestations that decrease the quality of life such as moderate fever, coldness in the legs, joint pains and headaches have been attributed to $M$. ozzardi infection (Batista et al. 1960b). Recently, the presence of ocular lesions has been reported as possibly associated with M. ozzardi infection (Branco et al. 1998, Cohen et al. 2008).

The microfilaria $M$. ozzardi was detected in Brazil in the 1940s and 1950s (Deane 1949, Deane et al. 1954, Lacerda \& Rachou 1956) and was described as a potentially extensive problem (Moraes 1958). Recently, some studies have shown that this filaria is still found with high prevalence (Medeiros et al. 2007, 2008) and that simuliids are incriminated in the parasite's transmission in Brazil (Cerqueira 1959, Shelley \& Shelley 1976, Shelley et al. 1980).

Financial support: FAPEAM (2205/05)

+ Corresponding author: jmedeiro@inpa.gov.br

Received 19 August 2008

Accepted 9 January 2009
Due to the absence of data and the importance of M. ozzardi for Amazonian populations, studies are still necessary to understand the geographical distribution of the cases, as well as the individual and cultural characteristics of the population in endemic areas that make them prone to infection. Indeed, eye lesions possibly associated with $M$. ozzardi have already been reported in the municipality of Pauini (Branco et al. 1998) and high prevalence rates were found in indigenous communities (Medeiros et al. 2007). Thus, our goal was to obtain data on human infection by $M$. ozzardi through comparison of prevalence rates between genders, as well as to examine the relationships between $M$. ozzardi infection and age and professional occupation. We also sought to identify the simuliid species involved in the transmission of M. ozzardi and to estimate the Parasitic Infection Rate (PIR) of the vectors.

\section{MATERIALS AND METHODS}

Study area and population - This study was performed in the Purus and Pauini riverine communities in the municipality of Pauini $\left(07^{\circ} 421^{\prime} \mathrm{S} 67^{\circ} 01^{\prime} \mathrm{W}\right)$, Amazonas (AM) (Fig. 1). The municipality of Pauini is located in southwest AM, about $900 \mathrm{~km}$ from Manaus. It has 17,092 inhabitants, with 6,970 in the urban zone and 10,122 in rural areas (IBGE 2000). The region is covered by native primary forest and presents long flood areas, accessible only by plane or boat. The rainy season is usually from November-March, with average annual temperatures between $24-26^{\circ} \mathrm{C}$, and a relative humidity between $85-95 \%$. The people live in small communities and the local economy is based on agriculture (mainly cassava) and fishing.

The study was carried out in communities selected at random. The sample size was determined by assuming 


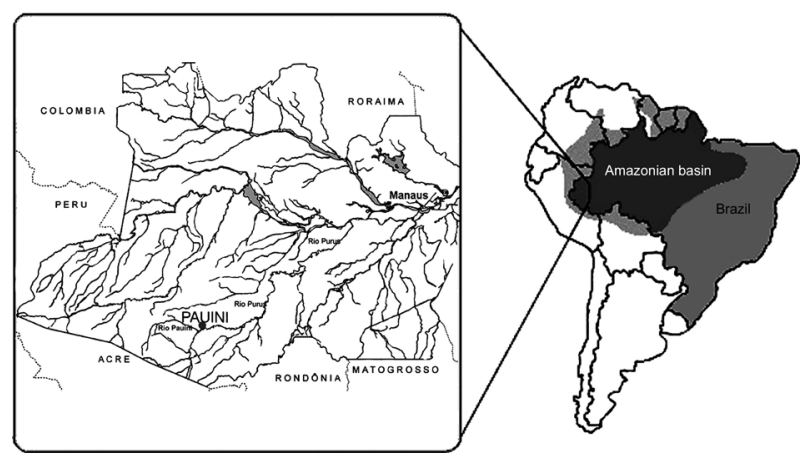

Fig. 1: A: state of Amazonas, showing the municipalities of Pauini region; B: Brazil: dark area, the position of the state of Amazonas.

an expected prevalence of microfilaremia of $10 \%$ with an error of 5\% and confidence interval of $99 \%$. In total, 921 people over two years old (mean $=24.64 \pm 18.13$ ) living in 35 communities (5 communities on the Pauini River and 30 on the Purus River) were examined by Rapid Epidemiological Mapping for microfilariae (mf) of $M$. ozzardi in November 2004, May 2005 and April 2006.

Parasitologic examination and ethical considerations - We examined individuals, taking into account sex, age group (2-9, 10-18, 19-27, 28-37, 38-47, 48-57, 58-67 and $\geq 68$ years), occupation (farmers, fishermen, housewives, students and teachers), as well as retired and handicapped people (blind and paraplegics), following Medeiros et al. (2008). The evaluation of M. ozzardi prevalence was done using thick blood smears obtained by digital puncture. We collected two drops of blood (about $0.04 \mathrm{~mL}$ ) from each individual and placed them on a slide. After air-drying, the blood was dehaemoglobinised in methylene blue, stained with Giemsa and microscopically examined (200X and 400X). When the blood smears were positive, the $\mathrm{mf}$ was identified following Post et al. (2003). This study was approved by the Ethical Committee of the Instituto Nacional de Pesquisas da Amazônia (protocol n. 043/2005), Manaus, AM, Brazil. Informed consent was obtained from all adult participants during meetings with the community and from the parents of minors who participated in the study.

Entomological proceedings - Simuliids were caught in several communities through a rapid entomological assessment technique using manual suction collectors. Flies were identified in the laboratory, stained with acid haematoxylin and dissected. The collected simuliids were dissected into three parts (head, thorax and abdomen) using a stylet, under a stereoscopic microscope. Then, the dissected parts were placed on a slide, each one in its own drop of glycerine, covered with a cover slip and examined under a light microscope. When filarial worms were detected, we identified and quantified them by developmental stage (L1, L2 or L3) (Tidwell et al. 1980, Yarzábal et al. 1985). Additionally, the larval stages of $M$. ozzardi were also submitted to a new identification protocol using the polymerase chain reaction (Medeiros et al., unpublished observations). We calculated the PIR following Medeiros et al. (2007). Infectivity Rate (IR) was calculated as the number of females infected with stage L3 M. ozzardi divided by the number of females dissected, multiplied by 100 . We compared the number of larvae in each stage using a Wilcoxon signed ranked test. In this test, just the parasitised females were used as replicates and the comparison was paired by female.

Statistical analyses - To determine if there were differences in the prevalence between men and women, we ran a $t$-test paired by the communities. We then determined for both the men and women whether the prevalence was related to age (age class) using Spearman correlation. The occupations were grouped into two categories, "rural occupations" (such as fishermen and farmers who spent most of their time in the field) and "domiciliary occupations" (such as housewives, teachers and students). We determined the differences between people in rural and domiciliary occupations using a maximum likelihood chi-square G-test. After that, we ran additional G-tests to determine whether the difference observed in the prevalence between the two professional categories also occurred in all age classes.

\section{RESULTS}

All of the communities investigated showed infected people and all filarial infections were identified as $M . o z$ zardi. On the Pauini River, 44 (24.86\%) of the 177 individuals examined were infected with $M$. ozzardi. Of the $88 \mathrm{men}$ and 89 women examined, $28(31.82 \%)$ and $16(17.98 \%)$, respectively, were positive for $M$. ozzardi $\mathrm{mf}$. The highest community prevalence encountered was $37.20 \%$ (in the locality Ribeiro). Along the Purus River, 183 (24.6\%) of the 744 individuals examined had M. ozzardi. Of the 379 men and 365 women examined, 113 (29.82\%) and 70 (19.18\%), respectively, were positive for M. ozzardi (Table I). The prevalence of $M$. ozzardi infection in communities along the Purus varied from $8.69-56.25 \%$.

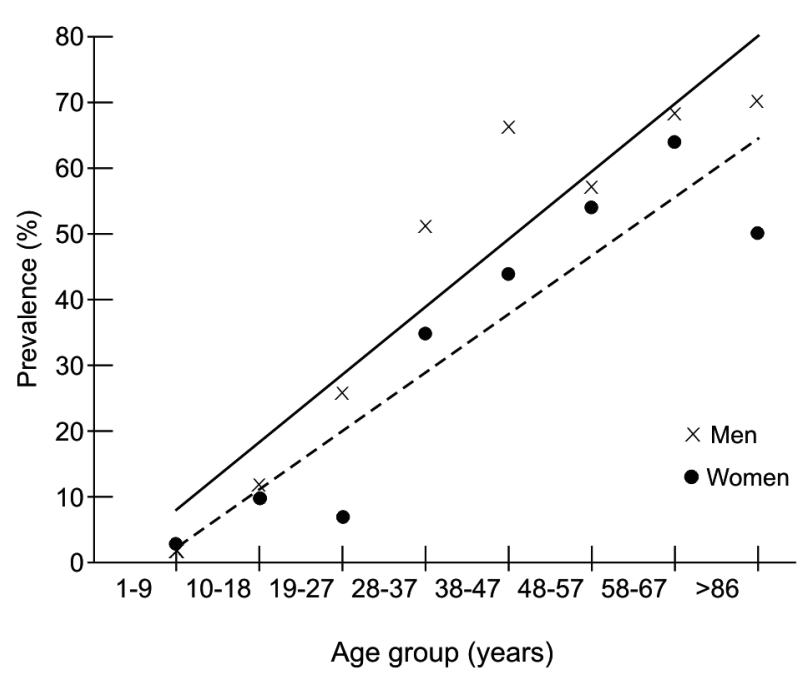

Fig 2: relation of age and prevalence of Mansonella ozzardi in the municipality of Pauni. The solid line represent the relation for men and the doted line, for women. Both relations were statistically significant using Spearman ranked correlation. 
TABLE I

Mansonella ozzardi infections in communities along the Pauini and Purus Rivers, municipality of Pauini, Amazonas, Brazil

\begin{tabular}{|c|c|c|c|c|c|c|}
\hline \multirow[b]{2}{*}{ Communities } & \multicolumn{3}{|c|}{ Positive/Examined } & \multicolumn{3}{|c|}{$\begin{array}{c}\text { Prevalence } \\
\%\end{array}$} \\
\hline & Males & Females & Total & Males & Females & Total \\
\hline \multicolumn{7}{|l|}{ Pauini River } \\
\hline Floresta & $4 / 10$ & $0 / 16$ & $4 / 26$ & 40.00 & 0 & 15.38 \\
\hline Guanabara & $6 / 11$ & $1 / 10$ & $7 / 21$ & 54.54 & 10.00 & 33.33 \\
\hline Castanho & $8 / 34$ & $2 / 27$ & $10 / 61$ & 23.53 & 7.41 & 16.39 \\
\hline Ribeiro & $8 / 22$ & $8 / 21$ & $16 / 43$ & 36.36 & 38.10 & 37.20 \\
\hline Maloca & $2 / 11$ & $5 / 15$ & $7 / 26$ & 18.18 & 33.33 & 26.92 \\
\hline Total & $28 / 88$ & $16 / 89$ & $44 / 177$ & 31.82 & 17.98 & 24.86 \\
\hline \multicolumn{7}{|l|}{ Purus River } \\
\hline Iça & $11 / 26$ & $7 / 29$ & $18 / 55$ & 42.31 & 24.14 & 32.72 \\
\hline Pauriã & $8 / 20$ & $1 / 15$ & $9 / 35$ & 40.00 & 6.66 & 25.71 \\
\hline Canta Galo & $1 / 4$ & $1 / 3$ & $2 / 7$ & 25.00 & 33.33 & 28.57 \\
\hline Canacuri I & $1 / 9$ & $2 / 11$ & $3 / 20$ & 11.11 & 18.18 & 15.00 \\
\hline Canacuri II & $7 / 25$ & $2 / 7$ & $9 / 32$ & 28.00 & 28.57 & 28.12 \\
\hline Boca Teuini & $3 / 21$ & $4 / 16$ & $7 / 37$ & 14.28 & 25.00 & 18.92 \\
\hline Maripuá & $1 / 3$ & $1 / 2$ & $2 / 5$ & 33.33 & 50.00 & 40.00 \\
\hline Morada Nova & $7 / 13$ & $5 / 12$ & $12 / 25$ & 53.58 & 41.67 & 48.00 \\
\hline Bananeiras & $2 / 11$ & $0 / 11$ & $2 / 22$ & 18.18 & 0 & 9.09 \\
\hline Vitória & $2 / 18$ & $4 / 26$ & $6 / 44$ & 11.11 & 15.38 & 13.63 \\
\hline Limoeiro & $2 / 11$ & $3 / 9$ & $5 / 20$ & 18.18 & 33.33 & 25.00 \\
\hline Pau Mulato & $1 / 6$ & $1 / 3$ & $2 / 9$ & 16.66 & 33.33 & 22.22 \\
\hline Tabocal & $4 / 8$ & $2 / 15$ & $6 / 23$ & 50.00 & 13.33 & 26.09 \\
\hline Guamã & $4 / 10$ & $6 / 16$ & $10 / 26$ & 40.00 & 37.50 & 38.46 \\
\hline Caraperi & $3 / 7$ & $0 / 1$ & $3 / 8$ & 42.86 & 0 & 37.50 \\
\hline São Miguel & $3 / 6$ & $0 / 6$ & $3 / 12$ & 50.00 & 0 & 25.00 \\
\hline Buenos Aires & $2 / 4$ & $3 / 13$ & $5 / 17$ & 50.00 & 23.07 & 29.41 \\
\hline Santa Elias & $3 / 15$ & $4 / 24$ & $7 / 39$ & 20.00 & 16.66 & 17.95 \\
\hline Santo Antonio & $1 / 14$ & $1 / 9$ & $3 / 22$ & 7.14 & 11.11 & 8.69 \\
\hline Sinibu II & $3 / 8$ & $0 / 7$ & $3 / 15$ & 37.50 & 0 & 20.00 \\
\hline Sinibu I & $2 / 8$ & $0 / 3$ & $2 / 11$ & 25.00 & 0 & 18.18 \\
\hline Boca do Mapiá & $2 / 12$ & $0 / 10$ & $2 / 22$ & 16.66 & 0 & 9.09 \\
\hline Inauini & $1 / 7$ & $5 / 16$ & $6 / 23$ & 14.28 & 31.25 & 26.09 \\
\hline Guajarã & $5 / 8$ & $4 / 8$ & $9 / 16$ & 62.50 & 50.00 & 56.25 \\
\hline Anisapé & $3 / 13$ & $3 / 14$ & $6 / 27$ & 23.08 & 21.42 & 22.22 \\
\hline Atalaia & $6 / 19$ & $3 / 20$ & $9 / 39$ & 31.57 & 15.00 & 23.07 \\
\hline Humaitá & $3 / 11$ & $1 / 14$ & $4 / 25$ & 27.27 & 7.14 & 16.00 \\
\hline Ajuricaba & $7 / 23$ & $2 / 23$ & $9 / 46$ & 30.43 & 8.69 & 19.56 \\
\hline Samoará & $7 / 16$ & $7 / 16$ & $14 / 32$ & 43.75 & 43.75 & 43.75 \\
\hline S. L. Mamuriá & $5 / 14$ & $2 / 15$ & $7 / 29$ & 35.71 & 13.33 & 24.14 \\
\hline Total & $113 / 379$ & $70 / 365$ & $183 / 744$ & 29.82 & 19.18 & 24.60 \\
\hline
\end{tabular}

The general prevalence in men was $31.82 \%$ along the Pauini River and $29.82 \%$ along the Purus River. However, in women this percentage was almost half that of the men $(17.98 \%$ and $19.18 \%$, respectively) (Table II). This difference between the sexes was highly significant (paired $t$-test, $\mathrm{t}=-3.434, \mathrm{df}=34, \mathrm{p}=0.001$ ). In both men and women, infection was positively associated with age (Spearman correlation $\mathrm{r}=0.976, \mathrm{p}<0.001 ; \mathrm{r}=0.905, \mathrm{p}$ $<0.001$, respectively) (Fig. 2). When age groups along the Pauini River were analysed, the lowest prevalence of infection was in the 2-9 and 10-18-year-old groups, with $0 \%$ and $9.76 \%$ positives, respectively. The prevalence began to increase in the 28-37 age group, in which 50\% of the examined subjects presented $M$. ozzardi microfilaria. The prevalence was highest among those older than 58. Along the Purus River, we also found the lowest infection rates in the 2-9-year-old group, in which $3.03 \%$ of the individuals were positive. The prevalence began to increase in 19-27-year-old men and 28-37-yearold women, and this rate was higher among males and women older than 38 .

In general, the individuals who work and/or spend the major part of their time in the rural zone showed much higher infection rates $(52.3 \%)$ than those who spend most of their time in domiciliary/urban environments $(13.6 \%)(\mathrm{G}=140.8, \mathrm{df}=1, \mathrm{p}<0.001)$. This accen- 
TABLE II

Prevalence of Mansonella ozzardi infections by age and sex in communities along the Pauini and Purus Rivers, municipality of Pauini, Amazonas, Brazil

\begin{tabular}{lcccccc}
\hline \multicolumn{2}{c}{ Males } & \multicolumn{2}{c}{ Females } & \multicolumn{2}{c}{ Total } \\
\hline Age group & Pos/Exam & $\begin{array}{c}\text { Prevalence } \\
\%\end{array}$ & Pos/Exam & $\begin{array}{c}\text { Prevalence } \\
\%\end{array}$ & $\begin{array}{c}\text { Prevalence } \\
\%\end{array}$ \\
\hline Pauini River & & & & & & \\
$2-9$ & $0 / 14$ & 0 & $0 / 14$ & 0 & $0 / 28$ & 0 \\
$10-18$ & $2 / 17$ & 11.76 & $2 / 24$ & 8.33 & $4 / 41$ & 9.76 \\
$19-27$ & $5 / 22$ & 22.73 & $1 / 21$ & 4.76 & $6 / 43$ & 13.95 \\
$28-37$ & $7 / 11$ & 63.66 & $4 / 11$ & 36.36 & $11 / 22$ & 50.00 \\
$38-47$ & $6 / 10$ & 60.00 & $3 / 9$ & 33.33 & $9 / 19$ & 47.37 \\
$48-57$ & $0 / 4$ & 0 & $3 / 6$ & 50.00 & $3 / 10$ & 30.00 \\
$58-67$ & $5 / 7$ & 71.43 & $2 / 3$ & 66.67 & $7 / 10$ & 70.00 \\
$\geq 68$ & $3 / 3$ & 100.00 & $1 / 1$ & 100.00 & $4 / 4$ & 100.00 \\
\hline Total & $28 / 88$ & 31.82 & $16 / 89$ & 17.98 & $44 / 177$ & 24.86 \\
\hline Purus River & & & & & & \\
$2-9$ & $2 / 82$ & 2.44 & $3 / 83$ & 3.61 & $5 / 165$ & 3.03 \\
$10-18$ & $12 / 101$ & 11.88 & $12 / 113$ & 10.62 & $24 / 214$ & 19.51 \\
$19-27$ & $16 / 59$ & 27.12 & $5 / 60$ & 8.33 & $21 / 119$ & 17.65 \\
$28-37$ & $22 / 45$ & 48.89 & $13 / 37$ & 35.13 & $35 / 82$ & 42.68 \\
$38-47$ & $25 / 37$ & 67.57 & $14 / 30$ & 46.67 & $39 / 67$ & 58.21 \\
$48-57$ & $16 / 24$ & 66.67 & $11 / 20$ & 55.00 & $27 / 44$ & 61.36 \\
$58-67$ & $8 / 13$ & 61.54 & $7 / 11$ & 63.64 & $15 / 24$ & 62.50 \\
$\geq 68$ & $12 / 18$ & 66.66 & $5 / 11$ & 45.45 & $17 / 29$ & 58.62 \\
\hline Total & $113 / 379$ & 29.82 & $70 / 365$ & 19.18 & $183 / 744$ & 24.60 \\
\hline
\end{tabular}

tuated difference, however, decreased with age (Fig. 3). Among those participants under age 48, there were differences in the prevalence of rural or domiciliary/urban workers, but among those over 48 , the differences were not statistically different (Fig. 3). The distribution of $M$. ozzardi among the occupational groups was described as follows: farmers (44.19\%), followed by fisherman (40\%), had the highest prevalence along the Pauini River. Along the Purus, farmers, teachers and retired people showed

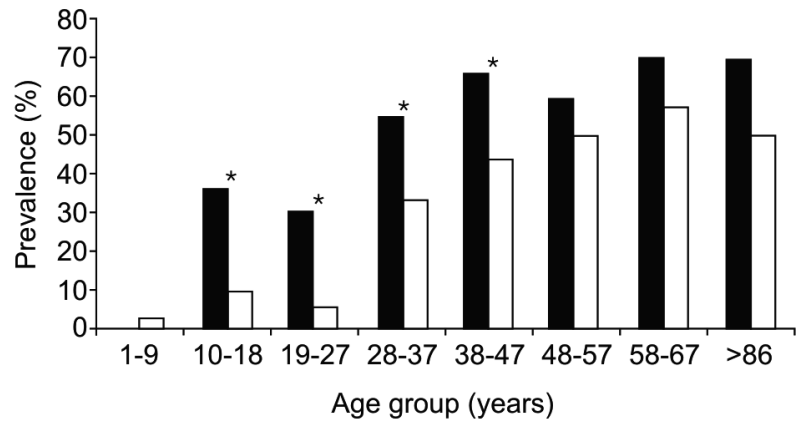

Rural occupation

Domiciliary occupation

Fig. 3: Mansonella ozzardi distribution by age group and occupation in communities along the Pauini and Purus Rivers, municipality of Pauini, Amazonas, Brazil. Asterisck correspond to statistical significant difference between occupation categories in different age groups, using G-test. a high prevalence, as well as housewives and fisherman. We found that the "handicapped people" $(75 \%)$ along the Purus River and all retired people along the Pauini were infected with $M$. ozzardi (Table III).

All of the collected blackflies were identified as Cerqueirellum amazonicum. Of the 19 communities where we collected simuliids, we found 15 with infected flies. We captured 1,104 simuliids in the Pauini River communities; five were parasitised, with a PIR of $0.45 \%$ and IR of $0.09 \%$. In the Purus River communities, we collected 3,056 simuliids and found 63 parasitised with a PIR of $2.06 \%$ and an IR of $0.39 \%$. The highest PIR and IR recorded were $8.43 \%$ and $3.61 \%$, respectively (Table IV).

Overall, significantly more simuliids were parasitised by filaria in the developmental stage L1 (31-49.20\%) than L2 (14-22.22\%) and L3 (6-19.05\%). The majority of $M$. ozzardi larvae were in stage L1 relative to those in stages L2 and L3 (Wilcoxon signed ranked test $\mathrm{Z}=-3.03$, $\mathrm{p}=0.002, \mathrm{z}=3.523, \mathrm{p}<0.001$ respectively).

\section{DISCUSSION}

M. ozzardi was found in all communities studied, and as a rule, the prevalence was greater in men than women and increased with age, independent of sex. However, the difference of prevalence was strongly correlated with economic activities. In occupations where individuals spent a lot of time in field conditions, the prevalence of infection was greater than in individuals in urban/domiciliary conditions. 


\section{TABLE III}

Distribution of Mansonella ozzardi infections by economic activities of individuals in communities along the Pauini and Purus Rivers, municipality of Pauini, Amazonas, Brazil

\begin{tabular}{|c|c|c|c|}
\hline Occupation & Examined & Positive & $\begin{array}{c}\text { Prevalence } \\
\%\end{array}$ \\
\hline \multicolumn{4}{|l|}{ Pauini River } \\
\hline Farmer & 64 & 27 & 44.19 \\
\hline Fisherman & 05 & 02 & 40.00 \\
\hline Housewife & 42 & 09 & 21.43 \\
\hline Student & 59 & 02 & 3.39 \\
\hline Teacher & 04 & 01 & 25.00 \\
\hline Retireds & 03 & 03 & 100.00 \\
\hline \multicolumn{4}{|l|}{ Purus River } \\
\hline Farmer & 161 & 84 & 52.17 \\
\hline Fisherman & 14 & 04 & 28.57 \\
\hline Housewife & 162 & 50 & 30.86 \\
\hline Student & 332 & 22 & 6.63 \\
\hline Teacher & 08 & 04 & 50.00 \\
\hline Non students $^{a}$ & 33 & 02 & 6.06 \\
\hline Retireds & 24 & 12 & 50.00 \\
\hline Without a formal occupation & 02 & 0 & 0 \\
\hline Handicapped people ${ }^{b}$ & 04 & 03 & 75 \\
\hline Other $^{c}$ & 04 & 02 & 50.00 \\
\hline
\end{tabular}

$a$ : children, 2-4 years old; $b$ : paraplegics and blind persons; $c$ : healthcare professionals, administrative assistant.

The prevalence in the Pauini population was higher than had been previously reported for the following municipalities of AM: Fonte Boa (17.8\%), São Paulo de Olivença (12.6\%), Uapés $(10.5 \%)$, Coari $(10 \%)$ and Codajas (23.9\%) (Lacerda \& Rachou 1956), Lábrea (4.4\% and 5.9\%) (Shelley 1975, Tavares 1981) and Coari (18.9\%) (Cohen et al. 2008). However, the prevalence was lower than that reported in the high Solimões (45.7\%) and Pauini (28.4\%) indigenous communities (Moraes et al. 1978, Medeiros et al. 2007). Indeed, a high prevalence has been found in some areas of Venezuela such as the state of Bolivar (36.4\%) and in the Amazon Federal Territory (30\%) (Medrano et al. 1980, Formica \& Botto 1990). In Colombia, infection was detected in the Comisaría del Valpes (47\%), Comisaría del Guainía $(20 \%)$ and Comisaría del AM (47.1\%) (Marinkelle \& German 1970, Kozek et al. 1982, 1983) and also in the Chaco region of Bolivia (26\%) (Bartoloni et al. 1999).

The prevalence of $M$. ozzardi increased with age in both men and women, and our results corroborate the observations of other investigators (Batista et al. 1960a, Moraes et al. 1978, Nathan et al. 1979, 1982, Kozek et al. 1982, 1983). Males seem to be infected with this filarial earlier in life than females; however, the infection is common in both after the 4th decade of life. The high prevalence rates among individuals in the age classes 28 37 and 38-47 indicates that infection is most likely acquired when individuals begin having higher exposure to vectors as a result of their daily activities. Thereafter, the increasing prevalence among those older than 58 is likely to be a continuous succession of overlapping in- fections. Some studies have pointed out cases of earlier infection (Biagi 1956, Tavares 1981), including infection diagnosed in a five-month-old child (Orihel 1967). In the communities along the Purus River, we found that $3.03 \%$ of the $0-9$-year-old age group were infected and the youngest infected individuals were four years old.

We observed more men infected with $M$. ozzardi than women. Previous studies carried out in different regions also found higher prevalence in males in Brazil (Shelley 1975, Moraes et al. 1978, Lawrence et al. 1980, Medeiros et al. 2007), Mexico (Biagi 1956), Colombia (Lightner et al. 1980, Kozek et al. 1982, 1983) and Trinidad (Nathan et al. 1979). This difference between the sexes may be a by-product of different occupations of males and females. The highest infection rates were found in farmers followed by fishermen, confirming again that individuals working in agricultural fields, in contact with the forest environment, or along river margins are more exposed to simuliids and therefore present a greater prevalence of infection than other occupations. On the other hand, most females stated that their day-to-day activities were centred close to home, so they were less exposed to the black flies. Our survey confirms the observation of other authors who also found the highest prevalence among outdoor workers (Batista et al. 1960a, Shelley 1975, Moraes et al. 1978, Tavares 1981); they especially found a higher prevalence of infection in farmers and rubber collectors. We also found a high prevalence of infection and microfilaremia among retired individuals. This is probably due to exposure to infective bites over many years with a continuous succession of overlapping infections.

In the Pauini region, we only collected $C$. amazonicum, which appears to be the only vector. The PIR was highly variable among communities, with some communities having rates up to $7.55 \%$ in Paurião and $8.43 \%$ in Tabocal along the Purus River. Shelley and Shelley (1976) found a PIR of $0.99 \%$ in simuliids captured along the Purus River in the municipality of Lábrea. Shelley et al. (1980) found a natural infection rate of 3.1\% in simuliids collected in communities on the high Solimões River. In spite of a low number of simuliids with L3 larvae, in some communities there was a high daily bite rate. This makes $C$. amazonicum an efficient vector species and compensates for the deficiency in the transmission capabilities (presence of a toothed cibarium). For example, in the rainy season, the bite frequency may be as high as 3,000 simuliid bites/person/day. Although $C$. amazonicum presents a toothed cibarium, we observed some simuliids with an elevated parasitic infection (e.g., $15 \mathrm{~L} 1 /$ simuliid, $15 \mathrm{~L} 1$ + 1L2/simuliid, 5L3 + 2L2/simuliid). Basáñez et al. (2002) found that the annual potential transmission was similar between several vector species with or without well-developed toothed cibarium and that the vector density was more important for vector competence than the presence of this structure.

We believe that the sampling was sufficiently representative to indicate the approximate local prevalence based on the examination of thick blood smears. Possibly, it would be greater with the use of a concentration method. In Codajás, the prevalence using blood films was $23.5 \%$ and increased to $41.4 \%$ when the Knott method was used (Moraes 1958). Even though the con- 


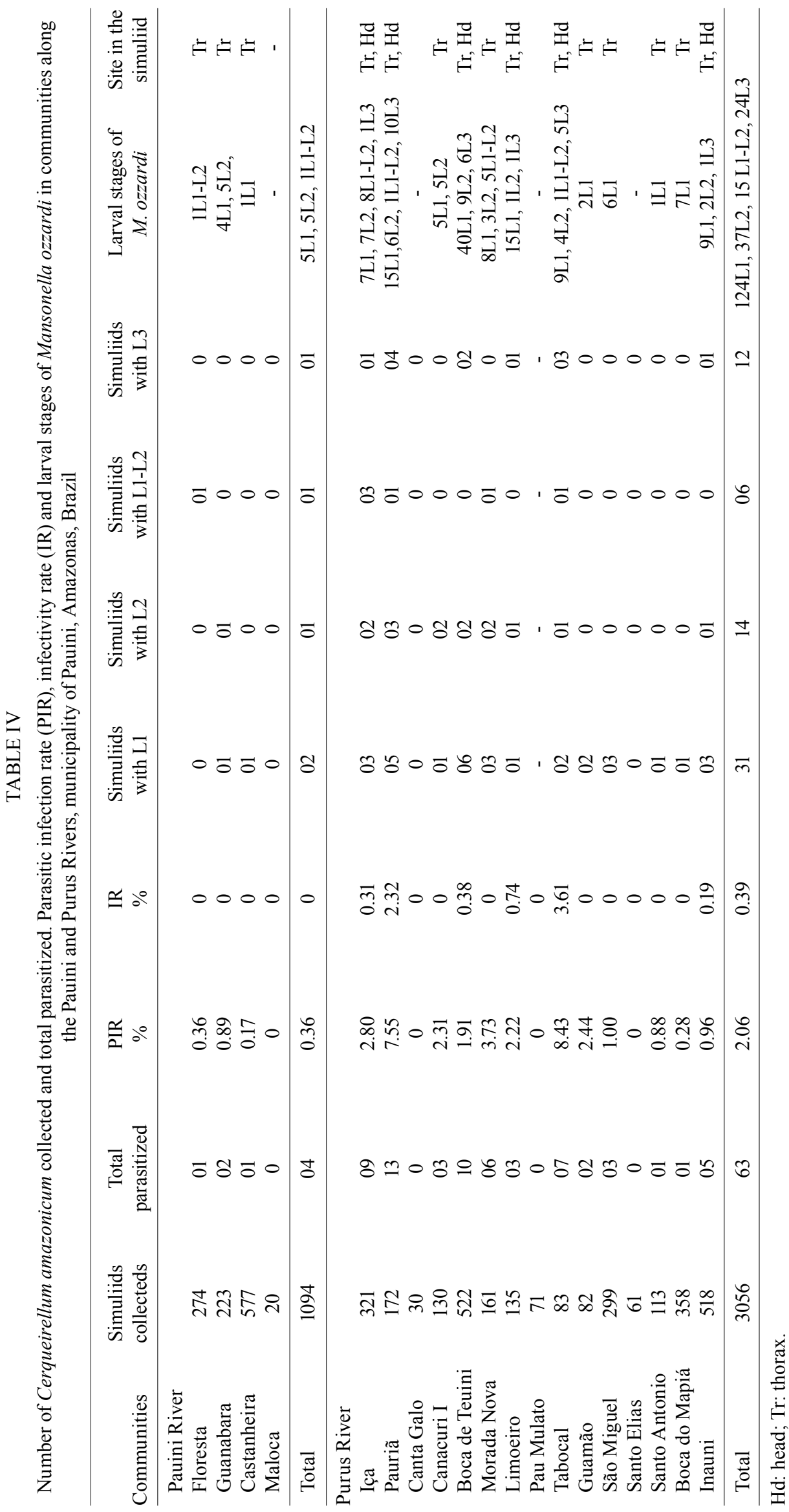


centration methods are the most sensitive in detecting M. ozzardi, they have several drawbacks that make their use less suitable in large scale work. This work confirms that rates of M. ozzardi infection are high in populations of the rural municipality of Pauini and, currently, there is no program for treating the population.

\section{ACKNOWLDEGMENTS}

To the government of the municipality of Pauini, as well as the local Fundação Nacional de Saúde, for logistical support, and to Lauro Camuça, Raimudo Acaraúbas, Manoel P. Silva and Raimundo S. Oliveira, for assistance during field work.

\section{REFERENCES}

Bartoloni A, Cancrini G, Bartelesi F, Marcolin D, Roselli M, Arce CC, Hall AI 1999. Mansonella ozzardi infection in Bolívia: prevalence and clinical association in the Chacon region. Am J Trop Med Hyg 61: 830-833.

Basáñez MG, Collins RC, Porter CH, Little MP, Brandling-Bennett D 2002. Transmission intensity and the patterns of Onchocerca volvulus infection in human communities. Am J Trop Med Hyg 67: 669-697.

Batista D, Cerqueira NL, Moraes MAP 1960a. Epidemiologia da mansonelose em localidade do interior do Amazonas. Rev Assoc Med Bras 6: 176-184.

Batista D, Oliveira WR, Rabello VD 1960b. Estudo da patogenicidade da Mansonella ozzardi e da sintomatologia da mansonelose. Rev Inst Med Trop Sao Paulo 2: 281-289.

Biagi FF 1956. Observaciones sobre mansonelosis em la Penísula de Yacatán. I: Frecuencia. Rev Med Mex 36: 521-526.

Branco BC, Chamon W, Belfort Neto R, Belfort Jr, Costa AJA 1998. Achados oculares entre habitantes do município de Pauini e possível associação entre lesões corneanas e mansonelose na Amazônia. Arq Bras Oftalmol 61: 674-682.

Cerqueira NL 1959. Sobre a transmissão da Mansonella ozzardi. J Bras Med 1: 885-914.

Cohen JM, Ribeiro JAS, Martins M 2008. Acometimento ocular em pacientes com mansonelose. Arq Bras Oftalmol 71: 167-71.

Deane L, Rachou RG, Lacerda NB, Martins JB 1954. Alguns dados relativos à prevalência de Mansonella ozzardi no Brasil. Rev Bras Malariol D Trop 6: 219-224.

Deane MP 1949. Sobre a incidência de filárias humanas em Manaus, estado do Amazonas. Rev Serv Esp Saude Publ 2: 849-858.

Formica S, Botto C 1990. Filariasis focus due to Mansonella ozzardi and Mansonella perstans in the Amazon Federal Territory of Venezuela. J Trop Med Hyg 93: 160-165.

IBGE - Instituto Brasileiro de Geografia e Estatística 2000. População e Domicílios - Censo 2000. Available from: www.ibge.gov.br.

Kozek WJ, D’Alessandro A, Suva J, Navarrete S 1982. Filariasis in Colombia: prevalence of mansonellosis in the teenage and adult population of the Colombian bank of the Amazon River, Comisaria del Amazonas. Am J Trop Med Hyg 31: 1131-1136.

Kozek WJ, Palma G, Henao A, García H, Hoyos M 1983. Filariasis in Colombia: prevalence and distribuition of Mansonella ozzardi and Mansonella (= Dipetalonema) perstans infections in the Comisaría del Guainía. Am J Trop Med Hyg 32: 379-384.

Lacerda NB, Rachou RG 1956. Filarioses humanas nas sedes municipais do estado do Amazonas e territórios do Acre, Guaporé e Rio Branco. Rev Bras Malariol Doenças Trop 8: 437-442.

Lawrence ND, Erdtmann B, Peet JW, Nunes de Mello JA, Hearl GR, James V, Neel MD, Salsano FM 1980. Estudos epidemiológicos entre populações indígenas da Amazônia. II. Prevalência da microfilaremia de $M$. ozzardi: comparação de dois métodos de diagnóstico. Acta Amaz 10: 763-769.

Lightner LK, Ewert A, Corredor A, Sabogal E 1980. A parasitologic survey for Mansonella ozzardi in the Comissaría Del Vaupés, Colombia. Am J Trop Med Hyg 29: 42-45.

Marinkelle CJ, German E 1970. Mansonellosis in the Comisaria del Vaupes of Colombia. Trop Geogr Med 22: 101-111.

Medeiros JF, Py-Daniel V, Barbosa UC, Farias ES 2007. Epidemiological studies of Mansonella ozzardi (Nematoda, Onchocercidae) in indigenous communities of Pauini municipality, Amazonas, Brazil. Acta Amaz 37: 241-246.

Medeiros JF, Py-Daniel V, Barbosa UC, Ogawa GM 2008. Current profile of Mansonella ozzardi (Nematoda: Onchocercidae) in communities along the Ituxi River, Lábrea municipality, Amazonas, Brazil. Mem Inst Oswaldo Cruz 103: 409-411.

Medrano C, Volcan G, Godoy GA 1980. Mansonelosis en el area Suroriental de la Orinoquia Venezolana. Rev Inst Med Trop Sao Paulo 34: 63-70.

Moraes MAP 1958. Contribuição ao estudo da mansonelose do Amazonas. O Hosp 54: 887-892.

Moraes MAP, Almeida MMR, Lovelace KJ, Chaves GM 1978. Mansonella ozzardi entre índios Ticunas do estado do Amazonas, Brasil. Bol Ofic Sanit Panam 85: 16-25.

Nathan MB, Tikasingh ES, Munroe P 1982. Filariasis in amerindians of Western Guyana with observations on transmission of Mansonella ozzardi by a Simulium species of the amazonicum group. Tropenmed Parasitol 33: 219-222.

Nathan MB, Tikasingh ES, Nelson GS, Santiago A, Davies JB 1979. The prevalence and distribution of Mansonella ozzardi in coastal north Trinidad, W.I. Trans Roy Soc Trop Med Hyg 73: 299-302.

Orihel TC 1967. Infection with Dipetalonema perstans and Mansonella ozzardi in the aboriginal indians of Guyana. Am J Trop Med Hyg 16: 628-635.

Post RJ, Adams ZA, Shelley AJ, Maia-Herzog M, Luna Dias APA, Coscarón S 2003. The morphological discrimination of microfilariae of Onchocerca volvulus from Mansonella ozzardi. Parasitology 127: 21-27.

Shelley AJ 1975. A preliminary survey of the prevalence of Mansonella ozzardi in some rural communities on the river Purus, state of Amazonas, Brazil. Ann Trop Med Parasitol 69: 407-412.

Shelley AJ, Coscarón S 2001. Simuliid blackflies (Diptera: Simuliidae) and Ceratpogonid midges (Diptera: Ceratopogonidae) as vectors of Mansonella ozzardi (Nematoda: Onchocercidae) in Northern Argentina. Mem Inst Oswaldo Cruz 96: 451-458.

Shelley AJ, Luna Dias APA, Moraes MAP 1980. Simulium species of amazonicum group as vectors of Mansonella ozzardi in the Brazilian Amazon. Trans R Soc Trop Med Hyg 74: 784-788.

Shelley AJ, Shelley A 1976. Further evidence for the transmission of Mansonella ozzardi by Simulium amazonicum in Brazil. Ann Trop Med Parasitol 70: 213-217.

Tavares AM 1981. Estudo da infecção por Mansonella ozzardi. Universidade de Brasília, Brasília, 122 pp.

Tidweel MA, Tidweel MA, Muños de Hoyos P 1980. Development of Mansonella ozzardi in a black fly species of the Simulium sanguineum group from eastern Vaupés, Colombia. Am J Trop Med Hyg 29: 1209-1214.

Yazarbal L, Basáñez MG, Ramírez-Pérez J, Ramírez A, Botto C, Yazarbal A 1985. Experimental and natural infection of Simulium sanchezi by Mansonella ozzardi in the middle Orinoco region of Venezuela. Trans R Soc Trop Med Hyg 79: 29-33. 